\title{
Družbena interakcija v ograjenem naselju z ekonomsko mešano sestavo prebivalstva v Cibuburju v Zahodni Javi
}

Ograjena naselja veljajo za škodljivo obliko urbane segregacije, saj so to varovane stanovanjske soseske z ekskluzivno infrastrukturo. Cilj indonezijske vladne politike, povezane z zagotavljanjem cenovno uravnotežene stanovanjske oskrbe, je ustvariti stanovanjske komplekse ali naselja z ekonomsko mešano sestavo prebivalstva, ki spodbujajo interakcijo med družbenimi sloji in zmanjšujejo čedalje večje socialne razlike. Namen članka je potrditi pojav družbene interakcije med socialno-ekonomskimi sloji v naseljih z ekonomsko mešano sestavo prebivalstva. Za boljše razumevanje družbene interakcije med stanovalci so avtorji najprej proučili razloge za izbor tovrstne stanovanjske soseske, in sicer za vsak socialno-ekonomski sloj posebej. $\mathrm{Za}$ to so uporabili metodo vrednotenja po vselitvi na primeru ograjenega naselja v Cibuburju v Za- hodni Javi, ki je znan po dobri kakovosti stanovanjskih sosesk in infrastrukture. Izsledki raziskave kažejo, da je varovanje še vedno glavni razlog za to, zakaj se ljudje odločijo živeti v tovrstnem ograjenem naselju. Zaradi manjše ekskluzivnosti naselja pa je čedalje manjša tudi pogostost uporabe tamkajšnje infrastrukture in površin, pripadniki posameznih družbenih slojev pa se raje kot s stanovalci istega stanovanjskega kompleksa v naselju družijo $s$ pripadniki istega sloja $\mathrm{v}$ drugih stanovanjskih kompleksih, kar se ne ujema s cilji politike cenovno uravnotežene stanovanjske oskrbe.

Ključne besede: stanovanjske preference, cenovno uravnotežena stanovanjska oskrba, ekonomsko mešana sestava prebivalstva, varovana soseska 


\section{Uvod}

$\mathrm{Na}$ stanovanjskem, urbanističnem in načrtovalskem področju razprave o ograjenih naseljih potekajo že vse od prejšnjega stoletja. V zadnjih treh desetletjih so ta naselja postala prevladujoča oblika stanovanjskih sosesk na vseh celinah (McKenzie, 2003), od Severne in Južne Amerike (Caldeira, 2000; Salcedo in Torres, 2004), Azije (King, 2004; Wu in Webber, 2004), Evrope (Gooblar, 2002) in Avstralije (Burke in Sebaly, 2001) do Afrike (Kuppinger, 2008). Po zgradbi so podobna starodavnim ograjenim mestom z začetka razvoja človeške civilizacije (Low, 2001; Landman in Schonteich, 2002; Quintal, 2006), kot je Jeriho (Dupuis in Thorns, 2008), znamenitosti Prepovedano mesto v Pekingu (Wu, 2005), tradicionalnim arabskim mestom (Glasze in Alkhayyal, 2002), srednjeveškim evropskim mestom in kolonialnim mestom po svetu (Blakely in Snyder, 1997). Simbolizirajo obsežne varnostne ukrepe, fevdalno aristokracijo srednjega veka in gospodarsko moč (Bekleyen in Dalkilıç, 2011).

Ograjena naselja ali skupnosti so opredeljena kot samoizolirane družbene skupine, ki se odločijo živeti v homogenih »enklavah « $s$ povsem določenim življenjskim slogom (Parker, 2006) in se zaščititi pred pretečim kriminalom $\mathrm{v}$ mestu (Harvey, 1999) tako, da se obdajo z zidovi z zavarovanimi vhodi (Low, 2003). Grant in Mittelsteadt (2004) sta jih opredelila tudi kot stanovanjske soseske z zasebnimi cestami, nedostopnimi za nestanovalce, in zavarovanimi glavnimi vhodi. Značilnosti, ki ograjena naselja ločijo od drugih naselij, so varnostni ukrepi in ovire, ograjenost, vključeni javni objekti in infrastruktura, vrsta stanovalcev, lokacija, velikost, lastniška struktura in stanovanjska politika. Atkinson in Flint (2004) ograjeno skupnost opredeljujeta kot skupino ljudi, ki prevzamejo kolektivno odgovornost tako, da se obnašajo v skladu s skupnimi pravili, določenimi s pravnimi dogovori. Blakely in Snyder (1997) ograjena naselja delita na tri vrste glede na razpoložljivo infrastrukturo, ekskluzivnost in varnost. Prva vrsta ograjenih naselij je povezana s prostočasnimi dejavnostmi ter raznimi rekreativnimi in drugimi objekti in površinami, ki so na razpolago. Temelji na novih življenjskih slogih in potrošniških vzorcih, ki so posledica globalizacije, ki daje prednost lastnim interesom (Caldeira, 1996). Druga vrsta so t. i. prestižne skupnosti, katerih ekskluzivnost se kaže v velikosti hiš, ki vključujejo razne storitve za zagotavljanje zasebnosti. Pri tretji vrsti ograjenih naselij pa je poudarjena večplastnost varovanja, ki je posledica zahtev stanovalcev po večji varnosti. Ograjena naselja zaradi varnostnih ukrepov in obdajajočih zidov (Low, 2003) obetajo varno, privilegirano in prestižno življenje (Erkip, 2003) ter preprečujejo prosto uporabo infrastrukture in padanje vrednosti nepremičnin (Le Goix, 2005).

\subsection{Cilji raziskave}

V Indoneziji so prva ograjena naselja začela nastajati v osemdesetih letih 20. stoletja z razvojem novih mest v okolici Džakarte (Winarso, 2005). Njihova gradnja je posledica periurbanizacije, ki je v interesu premožnih (Winarso idr., 2015), in okrepljene prostorske segregacije (Firman, 2004). Tovrstne ekskluzivne stanovanjske soseske stanovalce enega sloja ločujejo od stanovalcev drugih slojev, saj zmanjšujejo njihovo interakcijo z drugimi, zlasti revnejšimi prebivalci v okolici (Firman, 2004).

V osemdesetih letih 20. stoletja je vlada začela spodbujati tuje neposredne naložbe, ki naj bi pospešile gospodarsko rast (Leaf, 1994). Posledično je Džakarta do leta 1995 doživljala pravi nepremičninski razcvet, pri čemer se je cena zemljišč vsako leto trikrat povišala (Leaf, 1993). Gradnja ograjenih naselij se je razširila na bližnja mesta in občine, kot so Depok, mesto in občina Bogor, mesto in občina Tangerang, mesto Tangerang Selatan, ter mesto in občina Bekasi. Kot navajata Pribadi in Pauleit (2016), je bilo od osemdesetih let 20. stoletja v stanovanjske namene pozidanih skupno $200.000 \mathrm{ha}\left(20 \mathrm{~km}^{2}\right)$ zemljišč, pri čemer posamezno ograjeno naselje na metropolitanskem območju Džakarte zavzema približno $4,4 \mathrm{~km}^{2}$ (Karwita, 2016). To pomeni, da od tedaj delež novozgrajenih ograjenih naselij v celotni stanovanjski gradnji na metropolitanskem območju Džakarte dosega $25 \%$.

Leisch (2002) ugotavlja, da je velik delež ograjenih naselij na navedenem metropolitanskem območju posledica čedalje večjega števila premožnih prebivalcev, ki zahtevajo varnost in zaščito svojega prestižnega življenjskega sloga, ter verskih in etničnih razlik. Raziskava, opravljena v indonezijskem mestu Surabaya (Ginting in Sakinah, 2018), pa je, nasprotno, pokazala, da namen ograjenih naselij ni segregacija, in sicer na podlagi socialno-ekonomskega položaja in rase, ampak predvsem zagotavljanje varnosti. Druge raziskave ograjenih naselij v Indoneziji se osredotočajo na njihov pojav v mestnem okolju (Dick in Rimmer, 1998; Leisch, 2002), njihovo tipologijo, uporabo nadzorne tehnologije za zagotavljanje varnosti (Hishiyama, 2010), lokacijo ograjenih naselij (Ahmadi, 2005; Febby, 2010), položaj na nepremičninskem trgu (Aris, 2003; Rudiawan, 2008) in preference ljudi, da živijo v teh naseljih (Nurhadi, 2004; Tambunan, 2009; Handoko, 2011; Sueca in Fitriani, 2012). Povezava med stanovanjskimi preferencami in stopnjo zadovoljstva prebivalcev ograjenih naselij pa je še vedno slabo raziskana.

V ograjenih naseljih je več različnih skupin hiš ali stanovanjskih kompleksov, ki ustvarjajo sosesko z ekonomsko mešano 
sestavo prebivalstva, pri čemer mora biti v skladu s sprejetim zakonom o stanovanjih in naseljih št. 1/2011, vladno uredbo št. 14/2016 in odlokom ministrstva za javna stanovanja št. 10/2012, ki podpirajo cenovno uravnoteženo stanovanjsko oskrbo, razmerje med stanovanji za ljudi z nizkimi, srednjimi in visokimi dohodki $1: 2: 3$. Navedena zakonodaja določa število stanovanj za ljudi z nizkimi, srednjimi in visokimi dohodki v vsakem stanovanjskem naselju. Njen namen je ustvariti ravnovesje med socialno-ekonomskimi sloji v posameznih stanovanjskih skupnostih in zaradi omejenih virov vladno odgovornost $\mathrm{v}$ programih zagotavljanja stanovanj za ljudi z nizkimi dohodki prenesti na zasebni sektor. Navedeni predpisi od zasebnega sektorja v Indoneziji zahtevajo, da gradi ograjena naselja, v katerih si lahko stanovanje privoščijo pripadniki različnih družbenih slojev. Ti predpisi pričakovanih rezultatov niso dosegli, saj se cene nepremičnin stalno višajo, kar zasebnemu sektorju otežuje gradnjo stanovanj za ljudi z nizkimi dohodki v tovrstnih ograjenih naseljih. Zaradi tega je vlada leta 2015 na podlagi odloka ministrstva za javna stanovanja št. 7/2013 zasebnemu sektorju dovolila, da za revnejše stanovalce gradi ločena ograjena naselja na obrobju mest, kjer so cene zemljišč še vedno dovolj ugodne za gradnjo cenovno dostopnih stanovanj za pripadnike nižjih slojev. Zaradi novega odloka se zdaj na metropolitanskem območju Džakarte množično širi cenovno neuravnotežena stanovanjska oskrba v okviru ograjenih naselij.

Po mnenju mnogih strokovnjakov navedeni predpis ovira pričakovano družbeno interakcijo med različnimi socialno-ekonomskimi sloji v družbi. Pri tem se postavlja vprašanje, ali v ograjenih soseskah z ekonomsko mešano sestavo prebivalstva sploh poteka družbena interakcija med sloji, in če ne, zakaj ne. Drugo zanimivo vprašanje pa je, kako se socialno-ekonomski sloji v tovrstnih naseljih sploh oblikujejo. Namen članka je potrditi pojav družbene interakcije med socialno-ekonomskimi sloji v ograjenih naseljih z ekonomsko mešano sestavo prebivalstva in ugotoviti, zakaj ta interakcije sploh poteka. Izsledki raziskave bi lahko pomagali izboljšati indonezijsko stanovanjsko politiko z vidika povezave med tovrstnimi ograjenimi naselji in družbeno interakcijo med socialno-ekonomskimi sloji.

\section{Pregled literature}

\subsection{Negativne in pozitivne posledice ograjenih sosesk}

Pojav ograjenih naselij v ZDA je bil posledica čedalje večjih težav zaradi rasnih nemirov, mestnega nasilja in družbenih neenakosti ter množične selitve belcev srednjega razreda v predmestja v osemdesetih letih 20. stoletja (Sandercock, 2003). Nekateri raziskovalci pa trdijo, da je bil vzpon neoliberaliz- ma v navedenem obdobju (Leisch, 2002; Hackworth, 2007; Remali in Salama, 2016) razlog za hitro širjenje ograjenih naselij po vsem svetu, med drugim v Argentini (Thuillier, 2005), Čilu (Salcedo in Torres, 2004), Braziliji (Coy in Pohler, 2002), Savdski Arabiji (Glasze in Alkhayyal, 2002; Glasze idr., 2006), Gani (Asiedu in Arku, 2009), Južnoafriški republiki (Breetzke in Cohn, 2013), Bolgariji (Stoyanov in Frantz, 2006), Kanadi (Townshend, 2006), Angliji (Blandy, 2006), Indoneziji (Leisch, 2002), Vietnamu (Pow, 2009), Katarju (Rizzo, 2014; Zaina idr., 2016), Libanonu (Glasze in Alkhayyal, 2002), na Portugalskem (Raposo, 2006), na Novi Zelandiji (Dupuis in Thorns, 2008), v Avstraliji (Gleeson, 2006) ter celo v komunističnih državah, kot je Kitajska (Lee in Webster, 2006; Pow, 2007a, 2007b), in v postkomunističnih državah, kot so Estonija (Ruoppila in Kaehrik, 2003), Rusija (Blinnikov idr., 2006), Bolgarija (Hirt, 2012; Stoyanov in Frantz, 2006), Romunija (Negura, 2009), Srbija (Hirt in Petrović, 2011), Poljska (Mostowska, 2009), (Vzhodna) Nemčija in Madžarska (Bodnar in Molnar, 2010).

Obstoj ograjenih naselij kot oblike ekskluzivnih sosesk, kjer so stanovalci ločeni od drugih prebivalcev, so kritizirali številni raziskovalci (Low, 2003; Manzi in Smith-Bowers, 2005; Roitman, 2005). Obdajajoči zidovi take soseske preprečujejo povezavo in potrebo po interakciji njenih stanovalcev z nestanovalci (Burke in Sebaly, 2001), kar je v nasprotju z vladno politiko krepitve socialne kohezije na podlagi stalnega povezovanja med soseskami (Grant idr., 2004). Poleg tega ograjena naselja povečujejo družbeni prepad in nelagodje med državljani (Low, 2003; Sandercock, 2003), saj simbolizirajo neenakost med višjimi in nižjimi družbenimi razredi (Sanchez idr., 2005; Webster idr., 2006). Malezijske raziskave (Xavier, 2008; Lean in Smyth, 2012) kažejo, da strmo naraščanje vrednosti nepremičnin močno otežuje zagotavljanje cenovno dostopnih stanovanj v ograjenih naseljih. Kljub obljubam pa zidovi, varovani vhodi in videonadzor ograjenih naselij ne morejo zavarovati pred kriminalom. Izsledki raziskav, opravljenih v Južnoafriški republiki (Wilson-Doenges, 2000; Duca, 2015), Turčiji (Erkip, 2003) in Angliji (Atkinson in Blandy, 2005), kažejo, da ograjena naselja postanejo tarče kriminala, ob tem socialne kohezije, potrebne za njegovo preprečevanje, $\mathrm{v}$ teh naseljih ni. Zaradi negativnih posledic so se za ograjena naselja začeli uporabljati izrazi, kot so utrjene enklave (Caldeira, 2000), ekskluzivni ograjeni svetovi imunih skupnosti (Harvey, 1999), tiha in varna zavetja (Bauman, 2001), distopija izključenosti (Young, 1999), arhitektura strahu (Ellin, 1997) in celo arhitektura apartheida (Davis, 1998), ki ponazarjajo škodljive vplive tovrstnih naselij.

Kljub vsemu imajo ograjena naselja tudi pozitivne vplive. Med drugim omogočajo priložnost za izboljšanje kakovosti urbanističnega oblikovanja, infrastrukture in odprtih prostorov 
(Grant idr., 2004). Hiše, drugi objekti in infrastruktura so oblikovani in zgrajeni ob upoštevanju pravil, ki zagotavljajo udobno bivanje v urejeni soseski. Javno infrastrukturo in storitve $\mathrm{v}$ teh naseljih upravlja in vzdržuje zasebna samoupravna organizacija (Glasze idr., 2006). V njih so vzpostavljena skupna pravila ali zasebno upravljanje (Blandy in Lister, 2005), ki je učinkovitejše od javnega (vladnega) upravljanja. Grant (2005) ugotavlja, da tovrstno zasebno upravljanje zmanjšuje pritisk na javno upravo glede zagotavljanja in vzdrževanja javne infrastrukture.

Čeprav družbene vezi in socialna kohezija niso glavni dejavniki, ki vplivajo na to, da se ljudje odločijo živeti v ograjenem naselju (Blandy in Lister, 2005), postanejo občutno pomembnejši potem, ko ljudje dejansko v njem živijo (Garip in Şener, 2012). Razlog za to je, da živijo v zaprti soseski (Edgü in Cimşit, 2011) v okviru razmeroma homogenega družbenega razreda (Xavier, 2008), v katerem je vsem pomemben občutek varnosti (Grant, 2005). Ograjena naselja so poleg tega zatočišča za vse, ki ne sledijo uveljavljenim družbenim pravilom in normam. V Savdski Arabiji na primer zagotavljajo svobodo tistim, ki se ne strinjajo $s$ konservativno kulturo $\mathrm{v}$ državi (npr. ženskam in priseljencem; Odrowaz-Coates, 2015).

Ne glede na svoje negativne in pozitivne vplive ograjena naselja nastajajo zato, ker urbanistična politika in stanovanjska politika ne moreta zagotoviti varnega bivalnega okolja (Coy in Poehler, 2002; Glasze in Alkhayyal, 2002; Le Goix, 2005; Rosen in Razin, 2008). Na žalost veljajo za učinkovito obliko stanovanjske gradnje, ker so zasebni investitorji vključeni v sistem zagotavljanja javnih storitev (Foldvary, 1994). Kljub vsem težavam, ki jih povzročajo, mnoge vlade, med drugim tudi v ZDA (Blakely in Snyder, 1997; Low, 2003; McKenzie, 2006), niso naklonjene preprečevanju širjenja ograjenih naselij, saj ta prispevajo $\mathrm{k}$ davčnim dohodkom in zagotavljanju javne infrastrukture (Grant, 2005; Glasze idr., 2006).

\section{Raziskovalna metoda}

V skladu s cilji raziskave so se avtorji odločili za uporabo kvalitativnega pristopa in študije primera. Proučevano ograjeno naselje je v Cibuburju v indonezijski provinci Zahodna Java, ki je znan po dobri kakovosti sosesk in infrastrukture. Izbrano ograjeno naselje je veliko, saj pokriva približno 480 ha, dodatnih 270 ha pa je že določenih za prihodnjo gradnjo. Od leta 1997 je bilo v njem zgrajenih 48 stanovanjskih kompleksov za približno 8.700 stanovalcev in javna infrastruktura, kot so tržnica, šole, rekreacijske in športne površine, restavracije, verski objekti in prometna infrastruktura.
Zakonodaja, ki se uporablja, določa kategorije predvidenih stanovalcev $\mathrm{v}$ ograjenih soseskah z ekonomsko mešano sestavo prebivalstva na podlagi njihovih mesečnih prihodkov: stanovalci z manj kot 300 USD mesečnih dohodkov spadajo v nižji dohodkovni razred, stanovalci s (i) 300 - 600 USD oziroma (ii) 600 - 1.000 USD spadajo v srednji dohodkovni razred, tisti z več kot 1.000 USD dohodkov pa med premožne. Zasebni investitor je v skladu s predpisi za ograjene soseske z ekonomsko mešano sestavo prebivalstva zgradil različne vrste hiš. Posameznikom z nizkimi dohodki so tako namenjene hiše, velike $21 \mathrm{~m}^{2}$, posameznikom v prvi skupini srednjega dohodkovnega razreda (300 - 600 USD) hiše, velike $36 \mathrm{~m}^{2}$, posameznikom v drugi skupini srednjega dohodkovnega razreda (600 - 1.000 USD) hiše, velike od 45 do $60 \mathrm{~m}^{2}$, premožni pa lahko kupijo največje hiše, ki v povprečju obsegajo od 120 do $250 \mathrm{~m}^{2}$. Po navedbah upravnika naselja je bilo pred sprejetjem odloka ministrstva za javna stanovanja št. 10/2012 v proučevanem naselju zgrajenih 15 stanovanjskih kompleksov samo za srednji in visoki dohodkovni razred. Po sprejetju novega odloka leta 2012 sta bila samo dva kompleksa zgrajena v skladu z novimi zahtevami, dve leti pozneje, po sprejetju dopolnjene različice odloka, pa je bilo zgrajenih še preostalih 31 kompleksov, ki pa niso vključevali stanovanj za nizki dohodkovni razred. Avtorji so v raziskavo vključili stanovalce dveh stanovanjskih kompleksov z ekonomsko mešano sestavo prebivalstva, pri čemer sta bila kompleksa zgrajena v skladu z odlokom ministrstva za javna stanovanja št. 10/2012, da bi potrdili pojav družbene interakcije med družbenimi razredi v ograjenem naselju z ekonomsko mešano sestavo prebivalstva.

Da bi razumeli družbeno interakcijo med stanovalci z različnim socialno-ekonomskim položajem, so avtorji proučili razloge za izbiro stanovanja po posameznih dohodkovnih razredih. Analizirali so dejavnike, ki vplivajo na stanovanjske preference, in pomembnost varnostnih storitev in infrastrukture kot glavnih razlogov za to, da se ljudje odločijo živeti v ograjenem naselju z ekonomsko mešano sestavo prebivalstva. Poleg tega so proučili pogostost uporabe infrastrukture $\mathrm{v}$ naselju in pogostost družbene interakcije med stanovalci, da bi ugotovili, kako pogosto in kje poteka interakcija med stanovalci različnih socialno-ekonomskih slojev.

Ohranjanje zasebnosti in pomanjkanje zanimanja sta bili glavni oviri pri pridobivanju primarnih podatkov od stanovalcev ograjenega naselja $z$ anketo od vrat do vrat, čeprav sta upravnik in vodja naselja izdala dovoljenje za izvedbo ankete v obeh stanovanjskih kompleksih. Kljub izdanemu dovoljenju je upravnik zahteval, da ob kateri koli objavi, povezani z anketo, vsi podatki ostanejo anonimni. Od 480 stanovalcev, ki živijo $\mathrm{v}$ proučevanih stanovanjskih kompleksih z ekonomsko meša- 
Preglednica 1: Dejavniki, ki vplivajo na stanovanjske preference, glede na starost, spol in mesečni dohodek

\begin{tabular}{|c|c|c|c|c|c|c|c|c|c|}
\hline \multirow[t]{2}{*}{ Dejavnik } & \multirow[t]{2}{*}{ Splošno } & \multicolumn{2}{|c|}{ Starost (v letih) } & \multicolumn{2}{|l|}{ Spol } & \multicolumn{4}{|c|}{ Mesečni dohodek (v USD)* } \\
\hline & & $<45$ & $>45$ & M & Ž & $<300$ & $300-600$ & $600-1.000$ & $>1.000$ \\
\hline Varovanje & 1,61 & 1,88 & 1,36 & 1,56 & 1,65 & 2,29 & 2,57 & 2,90 & 4,07 \\
\hline $\begin{array}{l}\text { Kakovost in število javnih } \\
\text { objektov in površin }\end{array}$ & 1,75 & 1,95 & 1,53 & 1,63 & 1,85 & 1,57 & 2,36 & 1,80 & 2,53 \\
\hline Varnost & 2,06 & 2,21 & 1,89 & 2,00 & 2,10 & 2,29 & 3,00 & 2,10 & 2,81 \\
\hline Naložbene priložnosti & 2,39 & 2,37 & 2,42 & 2,44 & 2,35 & 2,00 & 2,36 & 2,10 & 2,79 \\
\hline Strateška lokacija & 2,39 & 2,37 & 2,38 & 2,37 & 2,41 & 2,29 & 3,21 & 2,20 & 3,24 \\
\hline Oblika stanovanj & 2,49 & 2,63 & 2,38 & 2,34 & 2,63 & 3,43 & 1,71 & 1,10 & 1,72 \\
\hline Socialna kohezija & 2,61 & 2,86 & 2,33 & 2,76 & 2,48 & 2,29 & 2,57 & 1,60 & 1,93 \\
\hline
\end{tabular}

Opomba: *1 USD $=15.000$ RIP

Preglednica 2: Pomembnost različnih oblik varovanja glede na starost, spol in mesečni dohodek

\begin{tabular}{|c|c|c|c|c|c|c|c|c|c|}
\hline \multirow{2}{*}{$\begin{array}{l}\text { Pomembnost različnih oblik } \\
\text { varovanja }\end{array}$} & \multirow[t]{2}{*}{ Splošno } & \multicolumn{2}{|c|}{ Starost } & \multicolumn{2}{|l|}{ Spol } & \multicolumn{4}{|c|}{ Mesečni dohodek (v USD)* } \\
\hline & & $<45$ & $45-65$ & $M$ & Ž & $<300$ & $300-600$ & $\begin{array}{l}600- \\
1.000\end{array}$ & $>1.000$ \\
\hline Zavarovan vhod v kompleks & 1,67 & 1,74 & 1,62 & 1,63 & 1,71 & 2,00 & 2,00 & 1,40 & 2,16 \\
\hline Redni varnostni obhodi & 1,75 & 1,91 & 1,62 & 1,63 & 1,85 & 1,57 & 2,36 & 1,60 & 1,66 \\
\hline Zavarovan glavni vhod & 1,91 & 2,00 & 1,84 & 1,76 & 2,04 & 2,29 & 3,64 & 2,20 & 3,02 \\
\hline Videonadzor v soseski & 2,01 & 2,02 & 2,02 & 1,76 & 2,23 & 2,14 & 2,86 & 2,70 & 3,91 \\
\hline Ločevalni zid & 2,08 & 2,00 & 2,18 & 1,95 & 2,19 & 2,14 & 1,71 & 1,50 & 2,76 \\
\hline Predpisi & 2,19 & 2,33 & 2,09 & 2,00 & 2,35 & 2,00 & 2,14 & 1,50 & 2,62 \\
\hline Zavarovan dostop do prostorov & 2,55 & 2,72 & 2,40 & 2,60 & 2,50 & 2,57 & 1,71 & 1,30 & 2,02 \\
\hline
\end{tabular}

Opomba: *1 USD = 15.000 RIP

no sestavo prebivalstva v ograjenem naselju, jih je v anketi na podlagi vzorčenja po metodi snežne kepe sodelovalo samo 89.

Avtorji so vse štiri vidike raziskave proučevali z uporabo petstopenjske Likertove lestvice, ki je uveljavljeno analitično orodje pri vrednotenju stanovanj po vselitvi (Hassanain, 2008; Najib idr., 2011; Owolabi, 2015; Eshaghi in Khozaei, 2016). Uporabili so jo za analizo pomembnosti dejavnikov, ki vplivajo na stanovanjske preference, in pomembnosti raznih oblik varovanja v ograjenem naselju ( 1 = zelo pomembno, 5 = najmanj pomembno) ter pogostosti uporabe razpoložljive infrastrukture in družbene interakcije ( 1 = najpogosteje, 5 = najmanj pogosto). Anketo so spremljali polstrukturirani intervjuji, s katerimi so avtorji proučevali vzrok povezav med prvimi tremi vidiki in razloge za družbeno interakcijo med stanovalci v stanovanjskih kompleksih z ekonomsko mešano sestavo prebivalstva.

\section{Izsledki in razprava}

\subsection{Pomembnost dejavnikov, ki vplivajo na stanovanjske preference}

Kot je razvidno iz preglednice 1, je bilo med 89 anketiranci glavni razlog za nakup in prebivanje $\mathrm{v}$ ograjenem naselju varovanje $(1,61)$, sledili so kakovost in število javnih objektov in površin $(1,75)$, značilnosti soseske $(2,06)$, naložbene priložnosti (2,39), strateška lokacija $(2,39)$, oblika hiš $(2,49)$ in socialna kohezija $(2,61)$. Za anketirance je bil pomemben dejavnik tudi strah pred kriminalom, saj se v Džakarti povečuje delež kaznivih dejanj v stanovanjskih soseskah (npr. kraje imetja in ugrabitve otrok). Pomembna je bila tudi razpoložljivost infrastrukture, saj v mestu primanjkuje kakovostnih javnih objektov in površin ali je teh zelo malo. Zaradi slabo zgrajene infrastrukture in brezbrižnih voznikov soseske niso varne, zlasti za starejše in otroke, zaradi česar ljudje najraje izberejo stanovanje v stanovanjskem kompleksu z ekonomsko mešano sestavo prebivalstva $\mathrm{v}$ ograjenem naselju. Zaradi varnosti, infrastrukture in strateške lokacije so stanovanja $\mathrm{v}$ ograjenih naseljih postala obetavna naložbena priložnost, ne glede na obliko ponujenega stanovanja. Socialna kohezija je med stanovalci ograjenega naselja na zadnjem mestu, čeprav še vedno velja za dokaj pomemben dejavnik.

Najpomembnejša dejavnika, ki vplivata na izbiro stanovanja, sta varovanje in razpoložljiva infrastruktura (Blakely in Snyder, 1997). Odgovori anketirancev, mlajših od 45 let, se ujemajo s splošnimi rezultati ankete (v stolpcu Splošno), pri anketirancih, starejših od 45 let, pa so opazne nekatere razlike. Zanje socialna kohezija ni najmanj pomemben dejavnik, saj je 
Preglednica 3: Pogostost uporabe infrastrukture v ograjenem naselju

\begin{tabular}{|c|c|c|c|c|c|c|c|c|c|c|}
\hline & & \multicolumn{9}{|c|}{ Infrastruktura v ograjenem naselju } \\
\hline & & $\begin{array}{l}\text { Kitajska } \\
\text { vas }\end{array}$ & Šport & Restavracije & Tržnica & Park & $\begin{array}{l}\text { Verski } \\
\text { objekti }\end{array}$ & Šola & Banka & $\begin{array}{l}\text { Avto- } \\
\text { bus }\end{array}$ \\
\hline \multirow{2}{*}{$\begin{array}{l}\text { Uporaba za lastne } \\
\text { potrebe }\end{array}$} & Pogostost & 4,48 & 3,40 & 2,39 & 1,57 & 3,65 & 1,89 & 2,58 & 2,25 & 3,58 \\
\hline & Korelacija & 0,03 & $(0,04)$ & 0,26 & 0,19 & 0,11 & 0,13 & $(0,09)$ & 0,11 & 0,16 \\
\hline \multirow{2}{*}{$\begin{array}{l}\text { Interakcija z dru- } \\
\text { gimi }\end{array}$} & Pogostost & 4,84 & 3,79 & 2,84 & 2,01 & 3,69 & 2,02 & 2,96 & 2,84 & 3,89 \\
\hline & Korelacija & $(0,02)$ & $(0,05)$ & 0,20 & 0,16 & 0,09 & 0,17 & 0,01 & 0,19 & 0,15 \\
\hline
\end{tabular}

pomembnejša od oblike stanovanj, strateške lokacije in naložbenih priložnosti. To kaže, da je socialna kohezija v ograjenem naselju še vedno pomembna potreba, ki jo je treba zadovoljiti, kar zagovarjajo tudi nekateri drugi raziskovalci (Edgü in $\mathrm{Ci}$ mşit, 2011; Garip in Şener, 2012).

\subsection{Pomembnost varovanja}

Kot je razvidno iz preglednice 2 , je za anketirance najpomembnejša oblika varovanja zavarovan vhod $\mathrm{v}$ stanovanjkki kompleks $(1,67)$. Sledijo redni varnostni obhodi $(1,75)$, zavarovan glavni vhod v naselje $(1,91)$, videonadzor v soseski $(2,01)$, zid, ki kompleks ločuje od preostale soseske (2,08), predpisi $\mathrm{v}$ soseski $(2,19)$ in zavarovan dostop do površin in prostorov, namenjenih stanovalcem kompleksa $(2,55)$.

Čeprav so izsledki podobni glede na starost in spol, se pomembne razlike pojavljajo med skupinami z različnimi mesečnimi dohodki. Za stanovalce $\mathrm{z}$ mesečnim dohodkom do 300 USD so najpomembnejši redni varnostni obhodi, in ne zavarovan vhod v stanovanjski kompleks, saj povzroča težave sorodnikom, ki živijo drugje in prihajajo v ograjeno naselje na obisk. Poleg tega so jim predpisi, ki stanovalce ozaveščajo o varnosti in varovanju v kompleksu, pomembnejši od zavarovanega glavnega vhoda in videonadzora. Prvi ovira obiske sorodnikov, drugi pa povečuje mesečne stroške vzdrževanja. V nasprotju z njimi je za stanovalce z višjimi dohodki (300 - 600 USD in $600-1.000$ USD) najpomembnejši zavarovan dostop do prostorov in površin, namenjenih izključno stanovalcem kompleksa. Drugi varnostni ukrepi so jim manj pomembni, saj si jih morajo deliti z ljudmi, ki ne živijo v istem stanovanjskem kompleksu in za katere se komaj zmenijo.

Navedene ugotovitve potrjujejo, da je pomembnost različnih oblik varovanja odvisna od njihove zmožnosti preprečevanja kriminala. Dodatna tehnologija, kot je videonadzor, je za večino anketirancev najmanj pomembna, saj povečuje njihove mesečne stroške, hkrati pa kriminala neposredno ne preprečuje.

\subsection{Pogostost uporabe infrastrukture v ograjenem naselju}

Iz preglednice 3 je razvidno, da se v naselju najpogosteje uporabljajo tržnica $(1,57)$, verski objekti $(1,88)$, banka $(2,25)$, restavracije $(2,39)$ in šola $(2,58)$. Anketiranci pa najredkeje uporabljajo športne objekte $(3,40)$, avtobus $(3,58), \operatorname{park}(3,65)$ in rekreacijsko območje Kitajska vas $(4,48)$. Čeprav je razpoložljivost infrastrukture med najpomembnejšimi dejavniki za življenje v ograjenem naselju, je njena korelacija s pogostostjo uporabe zanemarljiva. To pomeni, da je razpoložljiva infrastruktura med glavnimi privlačnimi prvinami stanovanjskega kompleksa z ekonomsko mešano sestavo prebivalstva, vendar jo stanovalci kompleksa redko uporabljajo za zadovoljevanje lastnih potreb.

Po mnenju anketirancev razpoložljiva športna infrastruktura ne ustreza potrebam stanovalcev. Uporaba nekaterih športnih objektov je predraga, zato jih večina ne uporablja. Športni objekti, kot sta fitnes in igrišče za golf, večine anketirancev ne zanimajo. Bolj so naklonjeni uporabi cenovno ugodnih skupnih objektov, kot sta bazen in športno igrišče. Nenaklonjenost uporabi poleg tega povečujejo številni obiskovalci od drugod, ki uporabljajo to infrastrukturo, zlasti ob koncu tedna. Dolge vrste pred napravami ter hrup in gneča $\mathrm{v}$ fitnesu ustvarjajo neprijetno ozračje za stanovalce. Podobno je z avtobusom, ki ga večinoma uporabljajo nestanovalci, da pridejo na obisk $\mathrm{k}$ sorodnikom ali pripotujejo v naselje, ker želijo uporabljati športne objekte in površine.

Čeprav so parki v ograjenem naselju prostorni in umetniško oblikovani in so stanovalcem vizualno všeč, jih neradi uporabljajo za piknike ob koncu tedna. Podobno ne želijo uporabljati drugih zunanjih objektov. Zaradi neprijetnega vlažnega tropskega podnebja se raje zadržujejo notri. Čeprav je rekreacijsko območje Kitajska vas primerno za oglede, privlači več obiskovalcev od drugod kot stanovalcev. Za stanovalce je to najmanj potreben objekt in ga uporabljajo samo za to, da tja peljejo sorodnike, ki pridejo na obisk (zlasti otroke). Ugotovitve kažejo neskladje med najpomembnejšimi dejavniki, ki vplivajo na stanovanjske preference, in pogostostjo uporabe razpoložljive infrastrukture. Infrastruktura je med glavnimi dejavniki, ki so vplivali na to, da so se anketiranci odločili živeti v ograjenem naselju (takoj za varovanjem), hkrati pa jo le redko uporabljajo. To je posledica različnih potreb in pomanjkanja ekskluzivnosti. Ker imajo do te infrastrukture dostop tudi nestanovalci, je izginil občutek varnega, privilegiranega in prestižnega življenjskega sloga (Blakely in Snyder, 1997; Erkip, 2003). 
Preglednica 4: Pogostost družbene interakcije med stanovalci ograjenega naselja

\begin{tabular}{|c|c|c|c|c|c|c|c|c|c|}
\hline \multirow[t]{2}{*}{ Pogostost interakcije } & \multirow[t]{2}{*}{ Splošno } & \multicolumn{2}{|c|}{ Starost } & \multicolumn{2}{|l|}{ Spol } & \multicolumn{4}{|c|}{ Mesečni dohodek (v USD)* } \\
\hline & & $<45$ & $45-65$ & $M$ & Ž & $<300$ & $\begin{array}{l}300- \\
600\end{array}$ & $\begin{array}{l}600- \\
1.000\end{array}$ & $>1.000$ \\
\hline $\begin{array}{l}\text { Z ljudmi, ki ne živijo v istem } \\
\text { kompleksu }\end{array}$ & 1,97 & 2,05 & 1,84 & 2,02 & 1,92 & 1,57 & 1,57 & 1,00 & 1,64 \\
\hline S stanovalci istega kompleksa & 2,72 & 2,81 & 2,60 & 2,83 & 2,63 & 2,29 & 3,29 & 2,00 & 2,71 \\
\hline $\begin{array}{l}\text { Z ljudmi, ki ne živijo v ograjenem } \\
\text { naselju }\end{array}$ & 3,61 & 3,67 & 3,56 & 3,66 & 3,56 & 3,86 & 2,50 & 1,60 & 2,72 \\
\hline
\end{tabular}

Opomba: ${ }^{*} 1$ USD $=15.000$ RIP

\subsection{Pogostost družbene interakcije med stanovalci ograjenega naselja}

Kot kaže preglednica 4, se anketiranci najpogosteje družijo z ljudmi, ki ne živijo v istem stanovanjskem kompleksu (1,97), nato pa s stanovalci istega kompleksa (2,72), ljudmi, ki ne živijo v ograjenem naselju $(3,61)$, in stanovalci ograjenega naselja (3,74). To kaže, da interakcija poteka na mestih, kot so tržnica ali športni objekti, kjer se anketiranci srečujejo $\mathrm{z}$ drugimi stanovalci naselja. V neposredni soseski stanovanjskega kompleksa interakcija poteka ob posebnih dogodkih, kot so proslave ob dnevu neodvisnosti, splošne volitve, poroka ali pogreb soseda. Anketiranci se najmanj družijo z ljudmi, ki ne živijo v istem naselju, a uporabljajo tamkajšnjo tržnico ali športne objekte.

Rezultati so podobni pri vseh anketirancih, ne glede na starost, spol in mesečni dohodek. Izjema sta samo skupini z mesečnim dohodkom med 300 in 600 USD in 600 in 1.000 USD, ki se pogosteje družita $\mathrm{z}$ ljudmi, ki ne živijo v ograjenem naselju, kot pa s stanovalci istega kompleksa. Druženje poteka v prostorih in na površinah, ki jih uporabljajo tudi ljudje, ki ne živijo v ograjenem naselju, kar zmanjšuje možnost kaznivih dejanj v naselju. Po mnenju anketirancev tovrstno druženje ustvarja družbene vezi med stanovalci in nestanovalci ograjenega naselja, kar preprečuje pojav kaznivih dejanj v naselju.

Navedene ugotovitve se ne ujemajo z izsledki prejšnjih raziskav, ki kažejo, da je največja želja vseh stanovalcev ograjenih naselij segregacija ali ločenost od preostalih prebivalcev (Burke in Sebaly, 2001; Low, 2003; Manzi in Smith-Bowers, 2005; Roitman, 2005). S sprejetjem odloka ministrstva za javna stanovanja št. 10/2012 se je uspešno zmanjšal negativni vpliv segregacije $\mathrm{v}$ proučevanem ograjenem naselju, ne pa tudi $\mathrm{v}$ posameznih stanovanjskih kompleksih. Proučevano ograjeno naselje je delno prepustno in dostopno tudi za nestanovalce.

$\mathrm{V}$ posameznih stanovanjskih kompleksih se stanovalci redko družijo med sabo, razen če so iz iste družine ali družbene skupine. Interakcijo med različnimi socialno-ekonomskimi sloji zavirajo razni dejavniki, na primer pomanjkanje skupnih tem za pogovor in občutek večvrednosti. Stanovalci se raje družijo $s$ pripadniki istega socialno-ekonomskega sloja v okoliških stanovanjskih kompleksih kot pa s pripadniki drugih družbenih razredov v svojem kompleksu. Navedeno se delno ujema z ugotovitvami drugih raziskovalcev (Edgü in Cimşit, 2011; Garip in Şener, 2012), ki optimistično trdijo, da se v ograjenih naseljih $z$ ekonomsko mešano sestavo prebivalstva družbena interakcija in kohezija krepita. Po drugi strani je opazen vzorec interakcije s pripadniki istega družbenega sloja v drugih stanovanjskih kompleksih. V primerjavi z razmeroma homogenim družbenim razredom se $\mathrm{v}$ stanovanjskih kompleksih z ekonomsko mešano sestavo prebivalstva ne morejo razviti skupni interesi (Xavier, 2008). To kaže, da odlok ministrstva za javna stanovanja št. 10/2012 ni učinkovita rešitev za spodbujanje družbene interakcije v ograjenih naseljih z ekonomsko mešano sestavo prebivalstva.

\section{Sklep}

Da bi indonezijska vlada pomembno zmanjšala segregacijo, je začela spodbujati gradnjo stanovanjskih naselij z ekonomsko mešano sestavo prebivalstva na podlagi odloka ministrstva za javna stanovanja št. 10/2012, ki podpira cenovno uravnoteženo stanovanjsko oskrbo. Cilj odloka je spodbuditi družbeno interakcijo med stanovalci različnih socialno-ekonomskih slojev in z različnimi mesečnimi dohodki. Hkrati zmanjšuje ekskluzivnost ograjenih naselij z vidika uporabe infrastrukture in homogenosti družbenih razredov. Raziskava, predstavljena $\mathrm{v}$ tem članku, kaže, da so ograjena naselja z ekonomsko mešano sestavo prebivalstva neučinkovita pri spodbujanju družbene interakcije med stanovalci različnih socialno -ekonomskih slojev.

Varovanje je glavni razlog za to, da se ljudje odločijo živeti v ograjenem naselju. $\mathrm{V}$ tovrstnem naselju prebivajo predvsem zaradi slabe varnostne in druge infrastrukture, ki jo zagotavlja vlada. Poleg tega se želijo izogniti nesrečam ali kriminalu, saj vlada ni zmožna zavarovati njihovih družin. V raziskavi pa se je pokazalo tudi neskladje med pomembnostjo dejavnikov, ki vplivajo na stanovanjske preference, in pogostostjo uporabe razpoložljive infrastrukture. Infrastruktura je bila namreč med 
anketiranci najpomembnejši dejavnik, ki je vplival na njihove stanovanjske preference in odločitev, da živijo v ograjenem naselju, hkrati pa jo zelo redko uporabljajo. Navedeno je posledica različnih potreb in pomanjkanja ekskluzivnosti. Infrastruktura v ograjenem naselju torej ne spodbuja družbene interakcije med stanovalci različnih socialno-ekonomskih slojev.

Tudi družbena interakcija med stanovalci v istem stanovanjskem kompleksu je šibka. Različni socialno-ekonomski sloji imajo različne skupne interese, kar zavira interakcijo. Interakcija pa je opazna s pripadniki istega družbenega razreda v drugih stanovanjskih kompleksih. Navedeno dokazuje, da ograjena naselja z ekonomsko mešano sestavo prebivalstva niso učinkovita pri spodbujanju družbene interakcije med stanovalci različnih socialno-ekonomskih slojev. $Z$ a spodbujanje socialne kohezije pripadnikov različnih socialno-ekonomskih slojev v tovrstnih naseljih so zato potrebne naprednejše raziskave. Treba bi bilo dodatno proučiti prostorske vzorce družbene interakcije ter oblikovanje kakovostnih stanovanj in sosesk, na podlagi česar bi se lahko v prihodnje zmanjšale negativne posledice ograjenih naselij. Tudi izsledki raziskave, predstavljene v tem članku, so lahko uporabni za izboljšanje stanovanjske politike in ustvarjanje boljših stanovanj in sosesk z ekonomsko mešano sestavo prebivalstva $\mathrm{v}$ prihodnje.

\section{Zahvala}

Avtorji se zahvaljujejo direktoratu za raziskave in vključevanje skupnosti na univerzi v Indoneziji (DRPM UI) za finančno podporo v okviru programa Hibah Publikasi Internasional Terindeks Tugas Akhir (Hibah PITTA B) Tahun Anggaran 2019 (projekt št. NKB-0780/UN2. R3.1/HKP.05.00/2019) in oddelku za arhitekturo na tehniški fakulteti univerze v Indoneziji (FTUI) za pomoč pri raziskavi.

\section{Maria Lestari Olivia}

Department of Architecture, Faculty of Engineering, University of Indonesia, Depok City, West Java, Indonezija

E-naslov: marialestario@gmail.com

\section{Joko Adianto}

Department of Architecture, Faculty of Engineering, University of Indonesia, Depok City, West Java, Indonezija

E-naslov: joko.adianto@ui.ac.id

\section{Rossa Turpuk Gabe}

Department of Architecture, Faculty of Engineering, University of Indonesia, Depok City, West Java, Indonezija

E-naslov: rossa@ui.ac.id

\section{Viri in literatura}

Ahmadi, A. (2005): Faktor-faktor yang mempengaruhi perkembangan fisik area pinggiran kota berdasarkan aspek persepsi bermukim pada kota Sengkang Provinsi Sulawesi Selatan. Semarang, Diponegoro University.

Aris, R. (2003): Perilaku pengembang kecil dalam keputusan investasi di Bandung Raya. Magistrsko delo. Bandung, Bandung Institute of Technology.
Asiedu, A. B., in Arku, G. (2009): The rise of gated housing estates in Ghana: Empirical insights from three communities in Metropolitan Accra. Journal of Housing and the Built Environment, 24(3), str. 227-247. DOI: $10.1007 /$ s10901-009-9146-0

Atkinson, R., in Blandy, S. (2005): Introduction: International perspective on the new enclavism and the rise of gated communities. Housing Studies, 20(2), str. 177-186. DOI: 10.1080/0267303042000331718

Atkinson. R., in Flint, J. (2004): Fortress UK? Gated communities, the spatial revolts of the elites and time-space trajectories of segregation. Housing Studies, 19(6), str. 875-892.

DOI: $10.1080 / 0267303042000293982$

Bauman, Z. (2001): Community. Seeking safety in an insecure world. Oxford, Polity.

Bekleyen, A., in Dalkılıç, N. (2011): The influence of climate and privacy on indigenous courtyard houses in Diyarbakır, Turkey. Scientific Research and Essays, 6(4), str. 908-922. DOI: 10.5897/SRE10.958

Blakely, E. J., in Snyder, G. M. (1997): Fortress America: Gated communities in the United States. Washington, DC, Brookings Institution Press. DOI: $10.1177 / 000169939804100209$

Blandy, S. (2006): Gated communities in England: Historical perspectives and current developments. GeoJournal, 66(1-2), str. 15-26. DOI: 10.1007/s10708-006-9013-4

Blandy, S., in Lister, D. (2005): Gated communities: (Ne)gating community development? Housing Studies, 20(2), str. 287-301.

DOI: $10.1080 / 026730303042000331781$

Blinnikov, M., Shanin, A., Sobolev, N., in Volkova, L. (2006): Gated communities of the Moscow green belt: Newly segregated landscapes and the suburban Russian environment. GeoJournal, 66, str. 65-81. DOI: 10.1007/s10708-006-9017-0

Bodnar, J., in Molnar, V. (2010) Reconfiguring private and public: State, capital and new housing developments in Berlin and Budapest. Urban Studies, 47(4), str. 789-812. DOI: 10.1177/0042098009351188

Breetzke, G. D., in Cohn, E. G. (2013): Burglary in gated communities: An empirical analysis using routine activities theory. International Criminal Justice Review, 23(1), str. 56-74. DOI: 10.1177/1057567713476887

Burke, M., in Sebaly, C. (2001): Locking in the pedestrian? The privatised streets of gated communities. World Transport Policy and Practice, 7(4), str. 67-74.

Caldeira, T. P. R. (1996): Building up walls: The new pattern of spatial segregation in Sao Paulo. International Social Science Journal, 48(1), str. 55-66. DOI: 10.1111/j.1468-2451.1996.tb00056.x

Caldeira, T. P. R. (2000): City of walls: Crime, segregation, and citizenship in Sao Paulo. Berkeley, University of California Press.

Coy, M., in Pohler, M. (2002): Gated communities in Latin American megacities: Case studies in Brazil and Argentina. Environment and Planning B: Planning and Design, 29(3), str. 355-370. DOI: 10.1068/b2772x

Davis, M. (1998): Ecology of fear: Los Angeles and the imagination of disaster. New York, H. Holt.

Dick, H. W., in Rimmer, P. J. (1998): Beyond the third world city: The new urban geography of South East Asia. Urban Studies, 35(12), str. 23032321. DOI: $10.1080 / 0042098983890$

Duca, F. (2015): Gating in Johannesburg: Digging inside the social and political system of a golf estate and suburban suburb. V: Bagaeen, S., in Uduku, O. (ur.): Beyond gated communities: Urban gating and soft boundaries, str. 49-64. Oxon, UK, Routledge. DOI: 10.4324/9781315765976-4

Dupuis, A., in Thorns, D. (2008): Gated communities as exemplars of "forting up" practices in a risk society. Urban Policy and Research, 26(2), str. 145-157. DOI: 10.1080/08111140802026800 
Edgü, E., in Cimşit, F. (2011): Island living as a gated community: Place attachment in an isolated environment. A|Z ITU Journal of the Faculty of Architecture, 8(2), str. 156-177.

Ellin, N. (1997): Architecture of fear. New York, Princeton Architectural Press.

Erkip, F. (2003): The shopping mall as an emergent public space in Turkey. Environment and Planning A, 35(6), str. 1073-1093. DOI: 10.1068/ a35167

Eshaghi, A., Khozaei, F. (2015) Learning from architects' mistakes, a case study of three female students residence halls. Specialty Journal of Architecture and Construction, 1(3), str. 17-21.

Febby, A. (2010): Preferensi penghuni perumahan di kota Pekanbaru dalam menentukan lokasi perumahan. Jurnal Ekonomi Pembangunan, 12(1), str. 77-91. DOI: 10.23917/jep.v12i1.207

Firman, T. (2004): New town development in Jakarta metropolitan region: A perspective of spatial segregation. Habitat International, 28(3), str. 349-368. DOI: 10.1016/S0197-3975(03)00037-7

Foldvary, F. (1994): Public goods and private communities: The market provision of social services. Aldershot, VB, Edward Elgar.

Garip, S. B., in Sener, H. (2012) Analysing environmental satisfaction in gated housing settlements: A case study in İstanbul. A|Z ITU Journal of the Faculty of Architecture, 9(1), str. 120-131.

Ginting, S. W., in Sakinah, R. (2018): Gated community in Indonesian peri-urban: Security or segregation? IOP Conf. Series: Earth and Environmental Science, 202(1), str. 1-10.

DOI: 10.1088/1755-1315/202/1/012057

Glasze, G., in Alkhayyal, A. (2002): Gated housing estates in the Arab world: Case studies in Lebanon and Riyadh, Saudi Arabia. Environment and Planning B: Planning and Design, 29(3), str. 321-336.

DOI: $10.1068 / \mathrm{b} 12825 \mathrm{t}$

Glasze, G., Webster, C., in Frantz, K. (2006): Private cities: Global and local perspectives. London, Routledge.

Gleeson, B. (2006): Australia's heartlands: Making space for hope in the suburbs. Crows Nest, NSW, Allen \& Unwin.

Gooblar, A. (2002): Outside the walls: Urban gated communities and their regulation within the British planning system. European Planning Studies, 10(3), str. 321-334. DOI: 10.1080/09654310220121068

Grant, J. (2005): Planning responses to gated communities in Canada. Housing Studies, 20(2), str. 273-285.

DOI: 10.1080/026730303042000331772

Grant, J., Greene, K., in Maxwell, K. (2004): The planning and policy implications of gated communities. Canadian Journal of Urban Research, 13(1), str. 70-88. Dostopno na: fhttp://www.jstor.org/stable/ 44321057 (sneto 20. 2. 2019).

Grant, J., in Mittelsteadt, L. (2004): Types of gated communities. Environment and Planning B: Planning and Design, 31(6), str. 913-930. DOI: $10.1068 / \mathrm{b} 3165$

Hackworth, J. (2007): The neoliberal city: Governance, ideology, and development in American urbanism. Ithaca, NY, Cornell University Press. DOI: $10.7591 / 9780801461590$

Handoko, J. P. S. (2011): Pertumbuhan permukiman gated community di Yogyakarta: Perumahan-perumahan di Kabupaten Sleman Yogyakarta.

Yogyakarta: Proceeding Seminar Nasional SCAN\#2 Lifestyle and Architecture. DOI: 10.13057/psnmbi/m010419

Harvey, D. (1999): Justice, nature \& the geography of difference. Oxford, Blackwell.
Hassanain, M. A. (2008) On the performance of evaluation on sustainable student housing facilities, Journal of Facilities Management, 6(3), str. 212-225. DOI: 10.1108/14725960810885989

Hirt, S. A. (2012): Iron curtains. Gates, suburbs and privatization of space in the post-socialist city. Chichester, UK, Wiley-Blackwell. DOI: 10.1002/9781118295922

Hirt, S. A., in Petrović, M. (2011): The Belgrade wall: The proliferation of gated housing in the Serbian capital after socialism. International Journal of Urban and Regional Research, 35(4), str. 753-777. DOI: 10.1111/j.1468-2427.2011.01056.x

Hishiyama, K. (2010): Uneasy society in Indonesia: With special attention to the gated community and CCTV in Bali, Procedia Social and Behavioral Sciences, 2(1), str. 14-23. DOI: 10.1016/j.sbspro.2010.01.006

Kartiwa, A. (2016): Jaringan pengembang perumahan skala besar di Jabodetabek. Magistrsko delo. Bandung, Bandung Institute of Technology.

King, A. D. (2004): Spaces of global cultures: Architecture urbanism identity. New York, Routledge.

Kuppinger, P. (2008): Exclusive greenery: New gated communities in Cairo. City \& Society, 16(2), str. 35-61. DOI: 10.1525/city.2004.16.2.35

Landman, K., in Schonteich, M. (2002): Urban fortresses. Gated communities as a reaction to crime. African Security Review, 11(4), str. 71-85. DOI: 10.1080/10246029.2002.9628147

Le Goix, R. (2005): Gated communities: Sprawl and social segregation in southern California. Housing Studies, 20(2), str. 323-344.

DOI: 10.1080/026730303042000331808

Leaf, M. (1993): Land rights for residential development in Jakarta, Indonesia: The colonial roots of contemporary urban dualism. International Journal of Urban and Regional Research, 17(4), str. 477-491. DOI: 0.1111/j.1468-2427.1993.tb00236.x

Leaf, M. (1994): The suburbanization of Jakarta: A concurrence of economics and ideology. Third World Planning Review, 16(4), str. 341-356. DOI: 10.3828/twpr.16.4.n51557k1532xp842

Lean, H. H., in Smyth, R. (2013) Regional house prices and the ripple effect in Malaysia. Urban Studies, 50(5), str. 895-922. DOI: $10.1177 / 0042098012459582$

Lee, S., in Webster, C. (2006): Enclosure of the urban commons. GeoJournal, 66(1/2), str. 27-42. DOI: 10.1007/s10708-006-9014-3

Leisch, H. (2002): Gated communities in Indonesia. Cities, 19(5), str. 341-350. DOI: 10.1016/S0264-2751(02)00042-2

Libertun de Duren, N. R. (2006): Planning a la carte: The location patterns of gated communities around Buenos Aires in a decentralized planning context. International Journal of Urban and Regional Research, 30(2), str. 308-327. DOI: 10.1111/j.1468-2427.2006.00667.x

Low, S. (2003): Behind the gates: Life, security and the pursuit of happiness in fortress America. New York, Routledge. DOI: $10.4067 / \mathrm{s} 0250-71612003008700008$

Low, S. M. (2001): The edge and the center: Gated communities and the discourse of urban fear. American Anthropologist, 103(1), str. 45-58. DOI: 10.1525/aa.2001.103.1.45

Manzi, T., in Smith-Bowers, B. (2005): Gated communities as club goods: Segregation or social cohesion? Housing Studies, 20(2), str. 345-359. DOI: $10.1080 / 0267303042000331817$

McKenzie, E. (2003): Common-interest housing in the communities of tomorrow. Housing Policy Debate, 14(1 in 2), str. 203-234. DOI: 10.1080/ 10511482.2003.9521473

McKenzie, E. (2006): The dynamics of privatopia: Private residential governance in the USA. V: Glasze, G., Webster, C., in Frantz, K. (ur.): Private cities: Global and local perspectives, str. 9-30. London, Routledge. 
Mostowska, M. (2009): Provision of private services and enforcing neighbours' behaviour in one of Warsaw's gated neighborhoods. V: Smigiel, C. (ur.): Gated and guarded housing in Eastern Europe, str. 69-74. Leipzig, Leibniz-Institut für Länderkunde.

Najib, N. U. M., Yusof, N. A., in Abidin, N. Z. (2011) Student residential satisfaction in research universities. Journal of Facilities Management 9(3), str. 200-212. DOI: 10.1108/14725961111148108

Negura, O. (2009): Residential ensembles in "hypermodern times". A case study of their aspirations in Bucharest. V: Smigiel, C. (ur.): Gated and guarded housing in Eastern Europe, str. 59-68. Leipzig, Leibniz-Institut für Länderkunde.

Nurhadi, I. (2004) Preferensi masyarakat dalam memilih perumahan perkotaan di kota Tangerang studi kasus: Perumahan Banjar Wijaya, Poris Indah, dan Perumnas IV. Magistrsko delo. Semarang, Universitas Diponegoro. DOI: 10.31848/arcade.v1i2.16

Odrowaz-Coates, A. (2015): A gated community as a "soft" and gendered total institution. International Sociology, 30(3), str. 233-249. DOI: $10.1177 / 0268580915578759$

Owolabi, B.O. (2015). The effects of students' housing on academic performance at the University of Ibadan in Nigerian. International Journal of Scientific \& Engineering Research, 6(3), str. 1118-1132.

Parker, S. (2006): Theory of urban experience. Bologna, II Mulino.

Pow, C.-P. (2007a): Securing the "civilised" enclaves: Gated communities and the moral geographies of exclusion in (post)-socialist Shanghai. Urban Studies, 44(8), str. 1539-1558. DOI: 10.1080/00420980701373503

Pow, C.-P. (2007b): Constructing a new private order: Gated communities and the privatization of urban life in post-reform Shanghai. Social and Cultural Geography, 8(6), str. 813-833. DOI: 10.1080/14649360701712511

Pow C.-P. (2009): Public intervention, private aspiration: Gated communities and the condominisation of housing landscapes in Singapore. Asia Pacific Viewpoint, 50(2), str. 215-227.

DOI: $10.1111 / \mathrm{j} .1467-8373.2009 .01394 . x$

Pribadi, D. O., in Pauleit, S. (2016) Peri-urban agriculture in Jabodetabek Metropolitan Area and its relationship with the urban socioeconomic system. Land Use Policy, 55, str. 256-274.

DOI: 10.1016/j.landusepol.2016.04.008

Quintal, D. (2006): Gated communities in Sydney: A search for security. Diplomsko delo. New South Wales, University of New South Wales.

Raposo, R. (2006): Gated communities, commodification and aestheticization: The case of the Lisbon metropolitan area. GeoJournal, 66(1-2), str. 43-56. DOI: 10.1007/s10708-006-9015-2

Remali, A. M., in Salama, A. M. (2016): A chronological exploration of the evolution of housing typologies in Gulf cities. City Territory and Architecture, 3(14), str. 1-15. DOI: 10.1186/s40410-016-0043-z

Rizzo, A. (2014): Rapid urban development and national master planning in Arab Gulf countries. Qatar as a case study. Cities, 39, str. 50-57. DOI: 10.1016/j.cities.2014.02.005

Roitman, S. (2005): Who segregates whom? The analysis of a gated community in Mendoza, Argentina. Housing Studies, 20(2), str. 303-321. DOI: 10.1080/026730303042000331790

Rosen, G., in Razin, E. (2008): The rise of gated communities in Israel: Reflections on changing urban governance in a neo-liberal era. Urban Studies, 46(8), str. 1702-1722. DOI: 10.1177/0042098009105508

Rudiawan, R. (2008): Kajian pengembangan wilayah dan implikasinya terhadap bisnis dan investasi properti di Kabupaten Bandung Barat. Bandung, Bandung Institute of Technology.
Ruoppila, S., in Kaehrik, A. (2003): Socio-economic residential differentiation in post-socialist Tallinn. Journal of Housing and the Built Environment, 18(1), str. 49-73. DOI: 10.1023/A:1022435000258

Salcedo, R., in Torres, A. (2004): Gated communities in Santiago: Wall or frontier. International Journal of Urban and Regional Research, 28(1), str. 27-44. DOI: 10.1111/j.0309-1317.2004.00501.x

Sanchez, T. W., Lang, R. E., in Dhavale, D. M. (2005): Security versus status? A first look at the census's gated community data. Journal of Planning Education and Research, 24(3), str. 281-291. DOI: 10.1177/0739456X04270127

Sandercock, L. (2003): Cosmopolis II: Mongrel cities of the 21st Century. London, Continuum.

Stoyanov, P., in Frantz, K. (2006): Gated communities in Bulgaria: Interpreting a new trend in post-communist urban development. GeoJournal, 66(1-2), str. 57-63. DOI: 10.1007/s10708-006-9016-1

Sueca, N. P., in Fitriani, L. R. D. (2012): Profile gated community di Denpasar. Prosiding Temu IImiah IPLBI, str. 45-48. Bandung, Bandung Institute of Technology.

Tambunan, D. B. (2009): Atribut yang menjadi pertimbangan konsumen dalam membeli produk perumahan: Penelitian dan analisis conjoint. Jurnal Manajemen Bisnis, 2(2), str. 141-153.

Thuillier, G. (2005): Gated communities in the metropolitan area of Buenos Aires, Argentina: A challenge for town planning. Housing Studies, 20(2), str. 255-271. DOI: 10.1080/026730303042000331763

Townshend, I. J. (2006): From public neighborhoods to multi-tier private neighborhoods: The evolving ecology of neighbourhood privatization in Calgary. GeoJournal, 66, str. 103-120. DOI: 10.1007/s10708-006-9010-7

Webster, C, Wu, F., in Zhao, Y. (2006): China's modern gated cities. V: Glasze, G., Webster, C. in Frantz, K. (ur.): Private communities: Global and local perspectives, str. 153-169. Oxford, Routledge.

Wilson-Doenges, G. (2000): An exploration of sense of community and fear of crime in gated communities. Environment and Behavior, 32(5), str. 597-611. DOI: 10.1177/00139160021972694

Winarso, H. (2005): City for the rich. V: Cities of People: Papers of the 8th International Conference of the Asian Planning Schools Association Held on 11-14 September 2005 in Penang, str. 11-14. Penang, International Conference of the Asian Planning Schools Association.

Winarso, H., Hudalah, D., in Firman, T. (2015): Peri-urban transformation in the Jakarta metropolitan area. Habitat International, 49, str. 221-229. DOI: 10.1016/j.habitatint.2015.05.024

Wu, F. (2005): Rediscovering the "gate" under market transition: From work-unit compounds to commodity housing enclaves. Housing Studies, 20(2), str. 235-254. DOI: 10.1080/026730303042000331754

Wu, F., in Webber, K. (2004): The rise of "foreign gated communities" in Beijing: Between economic globalization and local institutions. Cities, 21(3), str. 203-213. DOI: 10.1016/j.cities.2004.03.002

Xavier, G. (2008): Gated and guarded communities-security concerns for elitist practice? Prispevek je bil predstavljen na konferenci z naslovom 5th Asian Law Institute Conference, ki je potekala od 22. do 23. maja v Singapurju. Tipkopis.

Young, J. (1999) The exclusive society: Social exclusion, crime and difference in late modernity. London, Sage.

Zaina, Samar, Zaina, Sara, in Furlan, R. (2016): Urban planning in Qatar: Strategies and vision for the development of transit villages in Doha. Australian Planner, 53(4), str. 286-301. DOI: 10.1080/07293682.2016.1259245 